\title{
AN EXPLORATORY CASE STUDY TO VALIDATE A METHOD FOR INVESTIGATING THE ROLE OF PMOS IN KNOWLEDGE TRANSFER
}

\author{
B. Tshuma ${ }^{1 * \#}$, H. Steyn ${ }^{1} \&$ C.C. van Waveren ${ }^{1}$
}

\section{ARTICLE INFO}

\section{Article details}

Submitted by authors $\quad 30$ Jul 2019

Accepted for publication 14 Feb 2020

Available online 31 Aug 2020

\section{Contact details}

Corresponding author tshucksly@gmail.com

Author affiliations

1 Department of Engineering and Technology Management, University of Pretoria, South Africa

\# $\quad$ Author was enrolled for a PhD in the Department of Engineering and Technology Management, University of Pretoria, South Africa

DOI

http://dx.doi.org/10.7166/31-2-2316

\section{ABSTRACT}

A conceptual model for the role of a project management office (PMO) in improving the usability of knowledge that is transferred between projects is proposed, and a method to investigate the role of PMOs in knowledge transfer is validated. The case of a PMO in a multinational engineering company was selected, and 24 codes within three themes were identified through qualitative data analysis of a semi-structured interview. Provisional support was found for three propositions related to three variables: the articulability of knowledge, the usability of knowledge, and the role of the PMO. The study fine-tuned a case study protocol for future investigation of the role of PMOs in improving the usability of knowledge that is transferred between projects.

\section{OPSOMMING}

'n Konseptuele model vir die rol van 'n projekkantoor in die verbetering van die bruikbaarheid van inligting wat tussen projekte oorgedra word, word voorgestel, en 'n metode om die rol van projekkantore in die oordrag van kennis te ondersoek is gevalideer. Die geval van 'n projekkantoor in 'n multinasionale ingenieursmaatskappy is gekies, en 24 kodes in drie temas is geïdentifiseer deur kwalitatiewe ontleding van 'n semi-gestruktureerde onderhoud. Voorlopige ondersteuning is gevind vir drie proposisies aangaande drie veranderlikes - naamlik, die artikuleerbaarheid van kennis, die bruikbaarheid van kennis, en die rol van die projekkantoor. Die studie het 'n gevalstudie protokol vir toekomstige ondersoek na die rol van projekkantore in die bruikbaarheid van kennis wat tussen projekte oorgedra word, verfyn.

The temporary and unique nature of projects [1], [2] poses a significant challenge to the management of projects. This has led to the widespread use and increased establishment of project management offices (PMOs) by project-based organisations (PBOs) [3] in their quest to manage projects effectively [4] and gain competitive advantage [5]-[8]. Knowledge management (KM) is one of the strategic functions of the PMO [3], [4], [9]-[14], and deals with evaluating, classifying, and structuring information so that others may benefit from its prior application, or easily apply it to a current problem [15]. Knowledge transfer (KT) is a KM process [16]-[19] through which one organisational unit is affected by the experience of another [7], and is a vital factor in the successful execution of projects. This necessitates the employment of useful KT practices [20] to improve the usability of knowledge that is transferred between projects.

Tshuma, Steyn and Van Waveren [21] developed a conceptual framework on the role of PMOs in the transfer of knowledge between projects. They argued that PMOs play an important role in the transfer of knowledge by supporting and facilitating the flow of knowledge across projects and that, without the PMO, this function cannot be effectively managed. Their framework shows that the PMO links knowledge generated and sent with knowledge received and used through its moderation and mediation roles. This improves the use and impact of knowledge, and increases the PBO's competitive advantage [21]. For the purposes of this paper, their framework was simplified to include only three variables, as shown in Figure 1. This model illustrates the role of PMOs in the transfer of knowledge with different levels of articulability to improve its usability. It is used to explore the role of PMOs in the transfer of knowledge with different levels of 
articulability in order to improve the usability of the transferred knowledge. This paper seeks to validate and fine-tune a case study protocol for future investigation of the model presented in Figure 1.

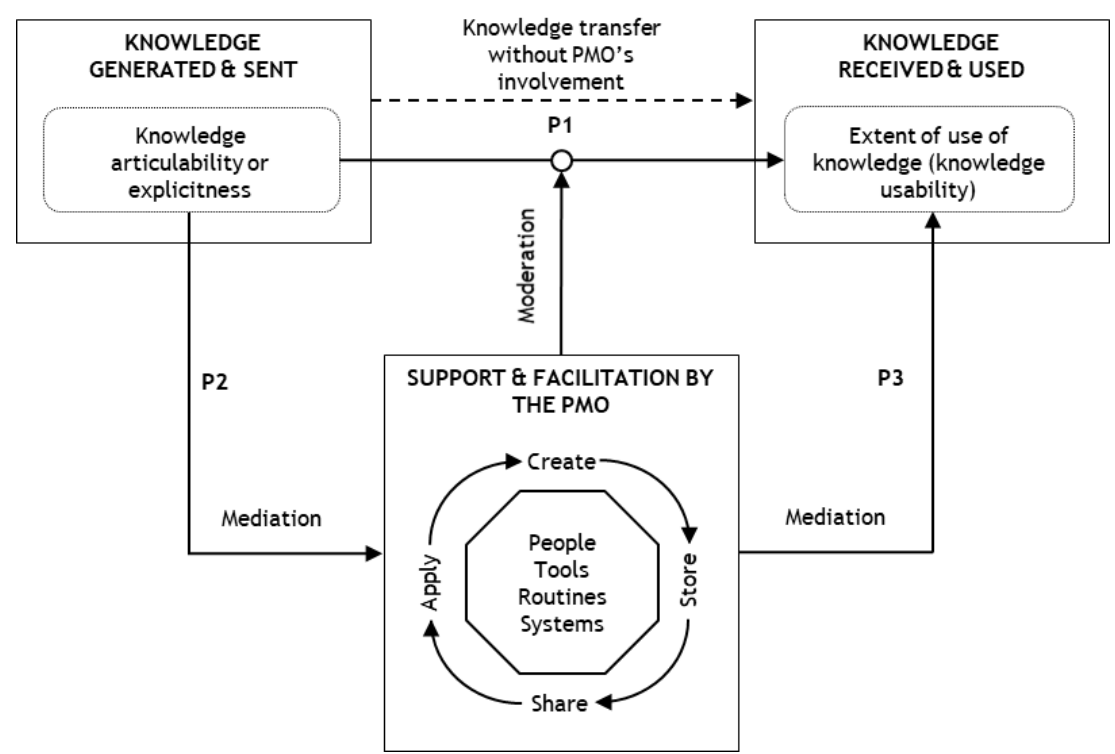

Figure 1: Conceptual model (adapted from Tshuma, Steyn, and Van Waveren [21])

'Knowledge articulability' is the extent to which knowledge can be verbalised, put into perspective, and/or written [22], and deals with the tacitness and explicitness of knowledge [23], [24]. The fact that articulated knowledge is easily captured, stored, and shared with other recipients, because it is pragmatic and easy to comprehend [23], proves that articulable knowledge can be more easily transferred than poorly articulated knowledge [22]. In other words, poorly articulated knowledge is difficult to diffuse, and thus hinders KT and knowledge usability (KU). However, both tacit and explicit knowledge are crucial in the creation and reuse of knowledge, and contribute positively to projects' success [25]. Codification and personalisation are the two strategies used by organisations to manage explicit and tacit knowledge respectively [6]. It is therefore what the PMO does to knowledge with different levels of articulability that determines the usefulness or extent of use of the knowledge.

The moderation (supporting) process influences, supports, and strengthens the KT relationship, thereby creating an interaction effect. For example, the PMO ensures that knowledge with different levels of articulability is transferred through the right process, at the right time, by the right methods/tools and the right people. Mediation (facilitation) serves to facilitate, adapt, improve, and clarify/explain the transferred knowledge. For example, the PMO adapts, improves, adds value, packages, and explains the transferred knowledge to make it more useful to the receiving project. Three propositions are derived from the model:

Proposition 1: The PMO's moderation (support) role assists in transferring knowledge with different levels of

Proposition 2: articulability at the right time, to the right recipients, to improve the usability of knowledge.

Proposition 3: The articulability of knowledge influences the PMO's mediation (facilitation) role. The PMO's mediation (facilitation) role improves the usability of knowledge.

PMOs mediate and moderate the transfer of knowledge between projects by embedding accumulated knowledge from past project experiences into project management routines that are used across multiple projects in the organisation [26]. Because the ability to consolidate learning from previous projects is crucial, the problem in the practical environment is that project employees usually do not get the time to share, evaluate, align, and capture the knowledge before moving on to the next project [27]. Their goals are project-specific and short-term in nature. PMOs, through their moderation and mediation roles, thus mitigate the risk of losing project knowledge emanating from time constraints on the project teams.

This paper describes the background of the case in Section 2, gives an overview of the research methodology adopted (Section 3), and presents the case study results and analysis in Section 4. Conclusions and recommendations are discussed in Section 5. 
The case of a PMO in the Wind Power Division of a multinational engineering company based in South Africa was investigated. The division specialises in the production of wind power turbines and accessories and in their transportation, installation, commissioning, operation, and maintenance. According to the definition of Curlee [28], this PMO is a decentralised one in which project managers share responsibility with the functional managers for assigning priorities and for directing the work of individuals assigned to the project. It supports two business units and projects of up to US\$400 million. It has five project managers, one project director, and three support staff.

\section{RESEARCH METHODOLOGY}

\subsection{Case study}

Although optional in case study research [29], exploratory case studies help researchers to sharpen their focus and to test the effectiveness of the proposed processes and procedures [29], [30]. As recommended by van Teijlingen and Hundley [31], this study was conducted to test the research methods, processes, and procedures, to generate codes and themes, and to use the results to fine-tune and improve the research questionnaire. Preliminary or preparatory studies are a crucial element of a good study [31] and a necessary initial step in exploring a novel intervention or an innovative application of an intervention [32]. They do not only serve as a risk mitigation measure to eliminate disappointments, mistakes, and delays in the main study, but are also used to evaluate the feasibility of randomisation, retention, and assessment procedures [32]. Holloway (1997) in [31] and Leon, Davis and Kraemer [32] argued that, in qualitative approaches, separate preliminary studies are not necessary. Qualitative data collection and analysis is often progressive, in that a subsequent interview in a series should be 'better' than the previous one, as the interviewer may have gained insights from previous interviews that can be used to improve interview schedules and specific questions. However, to avoid too many changes to the research design that may end up distorting the analysis of the results along the way, it is recommended that preparatory studies be conducted. Other reasons for conducting preparatory studies are:

- Developing and testing the adequacy of the research instruments, and assessing the feasibility of the main research;

- $\quad$ Designing a research protocol and assessing whether it is realistic and workable;

- $\quad$ Establishing whether the sampling frame and technique are effective;

- Identifying modifications needed in the design of a larger, subsequent proposition testing study;

- Collecting preliminary data and determining what resources (finance and personnel) are needed for the planned study;

- Assessing the proposed data analysis techniques to uncover potential problems; and

- $\quad$ Fine-tuning the research question and research plan.

Although preparatory studies represent a vital phase of the research process, they are not designed to test hypotheses or propositions [32]. The results of this study will not be included in the main study to avoid contamination and controversy - although van Teijlingen and Hundley [31] argue that contamination is less of a concern in qualitative research, in which researchers often use some or all of their pilot data as part of the main study. Only once the methods and procedures have been successfully validated can the data collection for the main investigation begin. Unlike the main case study reports, the preparatory study report should be clear about the lessons learned about the research design and the field procedures [29].

\subsection{Interviews}

While there are several kinds of data, all data fall into four basic categories: observations, interviews, documents, and audio-visual materials (Creswell (2007) in [33]). Researchers may use various techniques, but at the centre of qualitative research is the appetite to expose the human part of an experience. Qualitative researchers collect people's experiences to study various aspects of the human experience, and the primary mode for gathering stories is by interviewing people. Interviewing is a skill; and skilled interviewers can gain insight into lived experiences, learn the perspectives of individuals participating in a study, and discover the peculiarities in stories [33]. Interviews are a highly efficient way to gather rich empirical data, especially when the phenomenon of interest is sporadic and intermittent [34].

Since the execution of a good case study is dependent on the competence of the researcher [30] - asking the right questions, being flexible, having the ability to listen and objectively to interpret answers from respondents - are critical characteristics that the researcher needs to have [35]. Lack of these qualities 
may be detrimental to the overall success of the research. Less successful interviewers often miss the important points, while successful interviewers capture all the necessary information that will help in fully understanding the phenomenon being studied [36]. Qualitative interviewing helps to reconstruct events by putting together descriptions from different interviews [36] through the generation of codes and themes. Conducting qualitative interviews goes beyond having a conversation, in that interviews are more one-sided than ordinary conversations; the interviewer asks most of the questions, and the respondent provides most of the answers. Interviews usually focus on a research question and explore it in great depth, rather than moving on from one matter to the next without understanding the initial matter [36].

In this study, the respondent (the Wind Power Division PMO head) holds a master's degree, and has 20 years' experience in managing projects; two of those years have been in managing this PMO. The interview questionnaire was sent to her thirty days before the initial interview date to allow her time to go through the questions and an opportunity to ask for clarification and/or additional information before the interview date. A follow-up email was sent to her two weeks before the interview date, reminding her of the opportunity to ask for clarification and additional information. To mitigate the risk of having to deal with questionnaire clarification on the interview date, an informal short meeting between the researcher and the respondent is recommended. The purpose of such a meeting is for a brief overview of the study, the definition of terms, clarifying the questionnaire, and responding to any questions that arise. The informal meeting should take place at least a week before the interview date to allow the respondent to digest and make sense of the brief provided. The interview protocols of Jacob and Furgerson [33] have been used as a guideline in the preparation, analysis, and recommendations of the interview, as detailed in Annexure A.

\section{$4 \quad$ FINDINGS}

\subsection{Qualitative data analysis results}

Interview recordings collected from the interview were transcribed and captured in ATLAS.ti (a computeraided qualitative data analysis software [CAQDAS]). Twenty-four codes within three themes were established from the interview using ATLAS.ti as shown in Table 1. The principles adhered to during the analysis of the pilot study results were as follows:

- All relevant evidence is taken into consideration.

- $\quad$ All major rival interpretations are explored and understood.

- Most significant aspects of the case study are addressed.

- The analysis draws on the researcher's prior expert knowledge around the case study, but in an objective and unbiased manner.

\section{Table 1: Codes and themes generated}

\begin{tabular}{|c|c|c|c|c|}
\hline Theme & \multicolumn{4}{|c|}{ Codes } \\
\hline $\begin{array}{l}\text { 1. PMO's moderation } \\
\text { role in knowledge } \\
\text { transfer }(\mathrm{KT})- \\
\text { Proposition } 1\end{array}$ & $\begin{array}{l}\text { a) } \\
\text { b) } \\
\text { c) } \\
\text { d) } \\
\text { e) } \\
\text { f) } \\
\text { g) } \\
\text { h) }\end{array}$ & $\begin{array}{l}\text { Moderation: Communication } \\
\text { Moderation: Coordination meetings } \\
\text { Moderation: Creating relationships } \\
\text { Moderation: ICT } \\
\text { Moderation: Knowledge repository } \\
\text { Moderation: Knowledge sharing } \\
\text { Moderation: Lessons learnt } \\
\text { Moderation: People management }\end{array}$ & $\begin{array}{l}\text { i) } \\
\text { j) } \\
\text { k) } \\
\text { l) } \\
\text { m) }\end{array}$ & $\begin{array}{l}\text { Moderation: Reporting } \\
\text { Moderation: Storing and } \\
\text { securing } \\
\text { Moderation: Systems } \\
\text { Moderation: Tacit } \\
\text { knowledge transfer } \\
\text { Moderation: Training }\end{array}$ \\
\hline $\begin{array}{l}\text { 2. Influence of } \\
\text { articulability of } \\
\text { knowledge on } \\
\text { PMO's mediation } \\
\text { role - Proposition } \\
2\end{array}$ & $\begin{array}{l}\text { a) } \\
\text { b) } \\
\text { c) } \\
\text { d) }\end{array}$ & $\begin{array}{l}\text { Mediation: Communication } \\
\text { Mediation: ICT } \\
\text { Mediation: KM processes } \\
\text { Mediation: KM tools }\end{array}$ & e) & $\begin{array}{l}\text { Mediation: Knowledge } \\
\text { alignment } \\
\text { Mediation: Systems }\end{array}$ \\
\hline $\begin{array}{l}\text { 3. Effects of PMO's } \\
\text { mediation role on } \\
\text { knowledge usability } \\
\text { - Proposition } 3\end{array}$ & $\begin{array}{l}\text { a) } \\
\text { b) } \\
\text { c) } \\
\text { d) } \\
\text { e) } \\
\text { f) }\end{array}$ & $\begin{array}{l}\text { Mediation: Feedback } \\
\text { Mediation: ICT } \\
\text { Mediation: KM processes } \\
\text { Mediation: KM tools } \\
\text { Mediation: Knowledge alignment } \\
\text { Mediation: Knowledge dissemination }\end{array}$ & $\begin{array}{l}\text { g) } \\
\text { h) } \\
\text { i) }\end{array}$ & $\begin{array}{l}\text { Mediation: Knowledge } \\
\text { overload } \\
\text { Mediation: Lessons learnt } \\
\text { Mediation: People } \\
\text { management } \\
\text { Mediation: Systems }\end{array}$ \\
\hline
\end{tabular}

\subsection{PMO's moderation role in knowledge transfer - Proposition 1}

PMOs moderate (support) the transfer of knowledge across projects [21]. Their supporting role - which focuses on cultivating project management standards and methodologies, promoting a KT culture through 
organisational learning, and stimulating effective communication and the improvement of $\mathrm{KT}$ across projects - improves information and cooperation quality [37]. Since knowledge management (KM) infrastructure (people, tools, routines, and systems) and KM processes (create, store, share, align, protect, and use) are the main elements that drive KT in organisations [19], [22], [38], [39], their effective management determines the success of the PMO's moderation role in the transfer of knowledge across projects. PMOs must set up appropriate KM infrastructure and processes that promote a KT culture to improve the transfer of knowledge. The PMO therefore plays a pivotal role in demystifying this complex process to ensure that knowledge with different levels of articulability is transferred at the right time and to the right recipients, to improve its usability. Factors related to 'how the PMO's moderation role helps in transferring knowledge with different levels of articulability to improve the usability of knowledge;' are discussed in subsequent sections.

\subsubsection{Creation of awareness of importance of knowledge transfer (KT)}

The temporary nature of projects, in which project team members focus on the short-term goals of the project, often causes project personnel to fail to see the capturing and transferring of project knowledge across projects either as a priority or as important for long-term benefits to the organisation [40]. This makes knowledge capturing and transferring across projects a major challenge. To lay a strong foundation for effective KT, the PMO, through its moderation role, must create an environment in which project managers and project stakeholders acknowledge the importance of KT. Once an awareness of KT and of its importance has been created, the subsequent processes will be easy to accomplish. The respondent mentioned that weekly focus group coordination meetings were established by the PMO to create KT awareness, and that they are yielding the expected results. Project acceleration and coaching training (PACT), which normally takes place before a project is handed over to the project manager from the sales team; and this is very useful in creating knowledge transfer awareness and transferring the knowledge. The workshop is organised and supported by the PMO, and creates awareness of the importance of KT.

"But the most important for me is the handover that needs to happen from the sales perspective, and Sales hands over not only to the PM but also to the PMO because the PMO takes overall responsibility for that."

The success of knowledge internalisation could guarantee the successful creation of awareness of the importance of KT across projects, in that people invest energy, time, effort, and attention in the knowledge, and develop a commitment to knowledge to the extent that they see the value of knowledge and develop competence in using it [22].

\subsubsection{Improving trust and reducing insecurity to support knowledge transfer}

The literature suggests that one of the most critical factors determining cooperation performance is the degree of trust between the partners [41]-[43]. In this case, 'partners' refers to the various team members across projects in a PBO. Prinsloo, Van Waveren and Chan [44] list trust as one of the factors that impact knowledge dissemination in projects. Trust is essential for collaboration; it determines knowledge accessibility, and serves as the very foundation on which interaction takes place [45], [46]. It also increases cooperation and improves flexibility, lowering the cost of coordinating activities and increasing the level of KT and the potential for learning [41], [42], [47]. A failure to build a relationship based on mutual trust impedes KT across projects [42]. However, building trust among project team members is not an easy exercise [47], and PMOs could support the building of trust to ensure the success of the transfer of knowledge with different levels of articulability. According to the respondent, being guaranteed of a job is one way in which the PMO eliminates or reduces insecurity. People tend to share and transfer knowledge when they know that the knowledge they are sharing, and transferring will not be used by their colleagues as a competitive advantage.

Effective KT among project(s) team members in a project environment in which teams are temporary in nature is very challenging, since trust and shared understanding cannot be as easily built over a short period of time as with a permanent team [44]. This is based on the notion that "interpersonal trust is a prerequisite for knowledge sharing and transfer" [27]. Therefore, PMOs can play a very significant role in ensuring trust among various project team members by encouraging and cultivating a secure environment that improves interpersonal trust. Training provided by the PMO does not only increase an awareness of KT's importance, but also cultivates trust among employees and levels the playing field, thereby reducing the KT insecurity phenomenon. Trust acts as a governance mechanism by supporting and facilitating the extension of benefits to transacting partners, and by inviting the receiving party to reciprocate when an appropriate situation arises [42]. A strong employee social network cultivated by the PMO is important in building trust relationships [48]. 


\subsubsection{Creating a knowledge transfer culture to support knowledge transfer}

According to Schein (1995) in [49], 'organisational culture' refers to the values and views that are rooted in an organisation, and how they influence attitudes and behaviour. It consists of collaboration, trust, and a learning culture [49]-[51]. A learning culture opens formal and informal channels of communication, and a strong learning culture in organisations is linked to the creation, acquisition, and transfer of knowledge. To promote KT, PMOs must focus on the basic assumptions embedded in the organisational culture at hand, and not solely on direct KT between project managers [52]. To support KT between project managers, PMOs must focus on the concept of project organising, the reward system, and top management interaction, as these elements constitute the framework in which $\mathrm{KT}$ is supposed to take place [52]. Through a reporting system, the PMO coordinates the lessons learnt by reporting on a weekly basis and, through its moderation role, filters/screens and aligns knowledge that it then distributes to the right recipients in a summary format. The fact that this takes place on a weekly basis creates a KT culture in the PBO, as highlighted by the respondent:

"Well, they are forcing it down with the reporting. So, we all have access. It's a system, it's an IT tool, and you need to populate it on a weekly basis with highlights, lowlights, performance, safety, etc."

\subsubsection{Aligning the knowledge management (KM) infrastructure to support knowledge transfer}

A KM infrastructure consists of information communication technology(ICT), organisational culture and structure, and management and employees' support [5], [16], [25], [53], [54], and is the enabler of KT in organisations [19], [22], [38], [39]. As part of its KM function, the PMO structures and aligns the KM infrastructure to ensure that knowledge with different levels of articulability is transferred at the right time and to the right recipients to improve the usability of the knowledge. The PMO's role is to integrate, manage, and improve the systematic interaction of KT infrastructure and processes in an organisation [38]. Other knowledge management infrastructure that is used by the PMO - to ensure that knowledge with different levels of articulability is transferred to the right recipients at the right time - is the effective use and establishment of the appropriate ICT, tools, and people to transfer knowledge through both explicit methods (training, documentation, knowledge repositories) and tacit methods (coaching and transferring individuals with the required knowledge). To avoid each project from starting from scratch in terms of information and KT, Newell [55] suggests that the PMO use ICT to capture, store, and share project-based learning lessons from various projects so that they are able to transfer knowledge with different levels of articulability. The effectiveness of ICT in supporting KT might depend to a larger extent on the type of knowledge that is to be transferred [49]; and the PMO aligns and assigns each knowledge type with a specific ICT for successful transfer. The respondent indicated that the PMO structures ICT such that it supports KT by making knowledge accessible to all employees who need it.

"...there is no other way the PMO supports the creation of knowledge. It makes sure that it is rolled out and that everybody has access."

Since ICT supports all forms of KT [56], the PMO puts in place a highly developed ICT infrastructure to support the transfer of knowledge with different levels of articulability to improve the usability of the knowledge [50]. Successful KT is mainly linked to people, because learning and sharing knowledge are social activities that take place among people who support, facilitate, and coordinate the integration of diverse knowledge assets and combine theoretical and practical knowledge for effective KT [49], [57]. The PMO influences, identifies, and uses people who can integrate diverse knowledge assets to ensure that knowledge with different levels of articulability is transferred to the right recipient at the right time to improve its usability. The respondent indicated that the PMO encourages PMs to transfer knowledge through reporting and escalation to top management if the reporting has not been done. Furthermore, effective communication leads to a better alignment and transfer of knowledge.

\subsubsection{Aligning knowledge management processes to support knowledge transfer}

Knowledge management processes consist of knowledge creation and sourcing, compiling and transforming or aligning, disseminating/distributing/sharing, storing, applying, realising value, and ensuring its availability to future users [5], [16], [25], [53], [54]. The PMO's role is to integrate, manage, and improve the systematic interaction of KT infrastructure and processes in an organisation [38]. Furthermore, the PMO ensures that knowledge is not only shared or transferred but is also protected to preserve the organisation's competitive advantage. This is supported by the respondent's response:

“... in as much as you want to share lessons learnt, you do not want to share sensitive information - for example, project financials or contracts." 
The respondent emphasised that there is a support function in the PMO that manages access to the organisation's repository, to ensure that competitors do not get access to this unique knowledge. Decentralised structures facilitate knowledge sharing and collaboration [58], while high centralisation prevents interaction and frequent communication, and reduces creativity, innovation, and the need to share ideas among individuals [49]. Therefore decentralised organisational structures are more likely to support KT processes than centralised organisational structures [19]. To ensure that knowledge with different levels of articulability is transferred to the right recipient at the right time, the PMO encourages the decentralisation of PBOs; and where decentralisation cannot be achieved, it closely supports the KT across projects. Reporting is one of the tools used by the PMO to ensure effective KM processes. The PACT workshop and training, supported by the PMO, rolls out lessons learnt from previous projects, and improves tacit KT through which experiences from different project stakeholders are shared verbally.

\subsection{The PMO's mediation role in knowledge transfer - Propositions 2 and 3}

PMO leaders mediate cross-project learning by brokering project management practice connections between management, project teams, and other project stakeholders [59]. It is well-known that articulable knowledge is more easily transferable than less articulable knowledge; thus the possibility of successful KT increases as the articulability of the knowledge increases [22]. The articulability of knowledge, therefore, influences the PMO's mediation (facilitation) role in the KT process. The biggest challenge is whether to structure PMOs is such a way that they focus primarily on converting poorly articulated knowledge to articulable knowledge to increase KT success, or to structure PMOs so that they put in place KM infrastructure and processes that can effectively transfer both poorly articulated and articulable knowledge. The PMO must strike a balance between them - that is, converting poorly articulated knowledge, or setting up KT infrastructure and processes that support and facilitate the transfer of both poorly articulated and more articulable knowledge - for effective KT across projects.

\subsubsection{Influence of articulability of knowledge on PMO's mediation role - Proposition 2}

Knowledge transfer success is influenced by the articulability of the knowledge [22]. Tacit (less articulate) knowledge requires people to facilitate transfer and is difficult to diffuse among an organisation's employees. This hinders knowledge usability and success in KT, while explicit knowledge can be more easily transferred [22] and is best transferred through project management tools and systems [56], [60]. However, both tacit and explicit knowledge are crucial in the creation and re-use of knowledge, and both contribute positively to project success [25]. Tacit knowledge is arguably more valuable, and often leads to competitive advantage [24]. The PMO has to establish the extent of the articulability of the knowledge before attempting to explore and exploit it, since different kinds of knowledge and levels of articulability require different methodologies, techniques, mediums, and processes [21]. As noted by the respondent, feedback sessions between PMOs and projects are very important to ensure proper alignment and to limit discrepancies and misinterpretations:

"There is a process to say this needs to be in place by that time; but there is also feedback given to the PMO to say, how is the project doing, do we need support on certain functions?"

In some instances, the PMO decodes less articulated and complicated knowledge to improve its transferability to other projects, while in instances where decoding efforts may either be costly and/or impossible to do, PMOs may transfer an individual who holds the tacit knowledge [43] or may bring the seeker or receiver of the knowledge into contact with the individual who holds the tacit knowledge. Therefore, PMOs screen/filter, align, and disseminate the knowledge based on its articulability levels to improve the transfer of knowledge. Furthermore, PMOs decide on the KT mechanisms to be used for tacit and explicit knowledge to transfer knowledge effectively. To facilitate the transfer of tacit knowledge, PMOs establish a mentoring and coaching programme to support the individuals in building their experience of completing tasks in projects, or in the ability to express themselves clearly when sharing knowledge with other team members [44]. The articulability of received knowledge influences the PMO's mediation role by demanding that different systems and tools, such as ICT, be used for different levels of knowledge articulability. Since knowledge with different levels of articulability is received, it is the PMO's role to ensure that the appropriate ICT, routines, people, and processes are adopted and followed to transfer the knowledge. This was alluded to by the respondent.

Since the PMO's mediation role is influenced by the articulability of the knowledge, PMOs establish an integrated KT strategy incorporating tacit-oriented and explicit-oriented KT strategies [61]. Explicit knowledge is embedded in standardised procedures [24], provides the building blocks, and is often easier to transfer than tacit knowledge. Formalised KT mechanisms and procedures are thus established by PMOs for the transfer of explicit knowledge. The PMO uses standardised procedures suitable for the transfer of 
explicit knowledge, such as by ICT, and organisational routines and processes to effect transfer, unlike in the case of tacit knowledge transfer, which uses non-standardised mechanisms and procedures. The respondent mentioned the PACT workshop, training, and meetings where feedback among the PMO and projects is given, as some of the elements that support the above narrative.

\subsubsection{Effects of PMO's mediation role on the usability of knowledge - Proposition 3}

For the PMO's mediation role to improve the usability of the transferred knowledge, there must at least be effective communication and feedback between the PMO and the receiving project(s). First, the receiving project(s) should inform the PMO of their knowledge needs. Both parties could initiate this communication but, most importantly, it should be facilitated by the PMO through its mediation role, since most project team members focus on the current project and do not often see KT as one of their goals [40]. The PMO can reduce and/or eliminate the short-term goals focus of project team members by instilling a KT culture in all of them [52] by raising awareness of the importance of KT, communication, and feedback [22]. PMOs assist receiving projects to develop their absorptive capabilities [62], to ensure that the received knowledge is absorbed and used to full effect.

Second, the receiving project team members should be able to give feedback to the PMO on their success (or lack of success) in using the transferred knowledge for the continuous improvement of knowledge usability. Again, this could easily be achieved if a KT culture, effective communication, and effective feedback management is instilled in all project team members. The criteria to measure the success of the PMO's mediation role in the transfer and usability of knowledge are shown in Table 2.

Table 2: Dimension and criteria of measuring knowledge usability

\begin{tabular}{|c|c|c|c|}
\hline Variable & Measure(s)/Dimension & Criteria & Reference \\
\hline \multirow{5}{*}{$\begin{array}{l}\text { Knowledge } \\
\text { usability }\end{array}$} & $\begin{array}{l}\text { - Degree of user } \\
\text { friendliness }\end{array}$ & - Knowledge received is easy and simple to use & [63] \\
\hline & - Relevance & - Knowledge received is relevant to the situation & [63] \\
\hline & $\begin{array}{l}\text { - Expected use } \\
\text { (received and under } \\
\text { consideration) }\end{array}$ & $\begin{array}{l}\text { - Knowledge received is expected to be used or } \\
\text { not used }\end{array}$ & [64] \\
\hline & $\begin{array}{l}\text { - Conceptual use } \\
\text { (know about it) }\end{array}$ & $\begin{array}{l}\text { - Knowledge received caused a change in level of } \\
\text { knowledge and understanding } \\
\text { - Knowledge received caused change in attitude } \\
\text { and thinking behaviour }\end{array}$ & [64] \\
\hline & $\begin{array}{l}\text { - Instrumental and } \\
\text { strategic use (apply, } \\
\text { teach, share, and } \\
\text { improve own } \\
\text { understanding) }\end{array}$ & $\begin{array}{l}\text { - Knowledge received is applied in project(s) } \\
\text { - Knowledge received is used in decision-making } \\
\text { in project(s) } \\
\text { - Knowledge received is used to attain specific } \\
\text { power or goals } \\
\text { - Knowledge received is used as ammunition to } \\
\text { compete against competitors }\end{array}$ & [40], [64] \\
\hline
\end{tabular}

The PMO needs to filter, align, and disseminate knowledge so that the right knowledge is transferred to the right project(s) at the right time, rather than overloading the receiving project(s) with irrelevant knowledge. Language is often a barrier of communication; so, the PMO should transfer the knowledge in a language that is understood by the receiving project(s).

"... firstly, to clarify the knowledge and to make sure that we are talking one language. ... not just to take everything that is dumped and forward it to the next person. It doesn't make sense. It doesn't add value."

Furthermore, the PMO manages knowledge repositories consisting of knowledge generated from projects through lessons learnt, updated project management standards, and individualised learning turned into organisational learning [18]. PMOs store, protect, align, and transfer/share knowledge to the right recipient at the right time, to improve knowledge usability. The challenge with most knowledge repositories is that everybody dumps knowledge, and nobody knows what knowledge is available and when to transfer it [59]. The selective retention of existing, acquired, and created knowledge - information, documents, and experiments - in a properly indexed knowledge repository with search and retrieval functions [65] is PMO's mediation role that improves the usability of transferred knowledge. The PMO manages the knowledge repository; it manages the knowledge by determining what knowledge to transfer, and when and how to transfer it to the respective project(s), depending on the needs of the receiving project(s) [21].

In some instances, databases in the organisation point to experts in subject areas rather than providing actual knowledge. In this way, a community that supports specific subject needs in an organisation is 
formed. The transfer of knowledge is accomplished by interpersonal communications in a knowledge community, rather than by reliance on archived knowledge or knowledge repositories [66]; and the PMO facilitates this process, leading to improved knowledge usability. For organisations to generate and preserve a competitive advantage, it is vital that their knowledge be protected [58]. The PMO facilitates the protection of the organisation's knowledge from illegal or inappropriate use or theft. The respondent collaborated these statements about knowledge protection by indicating that not everyone in the PMO has access to all documents, to help protect the knowledge.

\section{CONCLUSIONS AND RECOMMENDATIONS}

A method to investigate the role of PMOs on knowledge transfer has been validated using the proposed conceptual framework for the role of PMOs in improving the usability of knowledge transferred between projects. The research method used in this research is suitable, as it has produced reliable and valid outcomes. The research method (protocols and processes) have been tested, codes and themes established, and findings correlated with the literature to pave the way for the main study. Valuable lessons that were learnt include advance warning about where the main research project could run into difficulties and possibly fail, where research protocols may not be followed, and whether the proposed methods or instruments are inappropriate or too complicated to implement [31]. Pitfalls encountered (see Annexure A) must be corrected and perfected before the main case studies are undertaken, to ensure robust and balanced investigations.

The outcomes of the investigation can assist researchers to develop and test the adequacy of the research instrument, assess the feasibility of the main study, fine-tune the research protocol, and make sure that the research protocol is realistic and workable. The validity and reliability of the results was satisfied as follows:

- Construct validity - The data collection questions and measures are linked to the research questions, the conceptual framework, and the research propositions; a chain of evidence is established; and the draft case study report has been reviewed by the respondent.

- Internal validity - Findings are attributed to interventions rather than to any flaws in the research design.

- $\quad$ External validity/generalisability - The limits of how far the study's findings can be generalised are clearly defined, and generalisation is based on replication logic.

- Reliability/consistency - A case study protocol (clearly documented research procedures and appropriate record-keeping) is in place to ensure that the operations of the study can be repeated and still obtain the same result(s), regardless of who the investigator is.

The lessons learnt from exploratory studies are used to increase the effectiveness and efficiency of the main research, and ultimately to improve the quality of investigations. To the qualitative researcher, this paper gives an insight into the advantages of carrying out a preparatory case study before conducting the main study, and even before adopting a research method.

\section{REFERENCES}

[1] Project Managment Institute. 2017. A guide to the project management body of knowledge (PMBOK guide), 6th ed. Project Management Institute, Inc.

[2] Aubry, M. \& Hobbs, B. 2010. A fresh look at the contribution of project management to organizational performance. Proj. Manag. J., 42(1), pp. 3-16.

[3] Hobbs, B. \& Aubry, M. 2007. A multi-phase research program investigating project management offices (PMOs): The results of phase 1. Proj. Manag. J., 38(1), pp. 74-86.

[4] Pinto, A., De Matheus Cota, M.F. \& Levin, D.G. 2010. The PMO maturity cube, a project management office maturity model. PMI Res. Educ. Congr. 2010, Washingt. D.C., USA, pp. 1-43.

[5] Hanisch, B., Lindner, F., Mueller, A. \& Wald, A. 2009. Knowledge management in project environments. J. Knowl. Manag., 13(4), pp. 148-160.

[6] Pretorius, C.J. \& Steyn, H. 2005. Knowledge management in project environments. South African J. Bus. Manag., 36(3), pp. 41-50.

[7] Argote, L. \& Ingram, P. 2000. Knowledge transfer: A basis for competitive advantage in firms. Organ. Behav. Hum. Decis. Process., 82(1), pp. 150-169.

[8] Lubit, R. 2001. Knowledge management: The keys to sustainable competitive advantage. Organ. Dyn., 29(4), pp. 164-178.

[9] Dai, C.X. \& Wells, W.G. 2004. An exploration of project management office features and their relationship to project performance. Int. J. Proj. Manag., 22, pp. 523-532. 
[10] Dietrich, P., Artto, K. \& Kujala, J. 2010. Strategic priorities and PMO functions in project-based firms. PMI Research Conference, Washington DC., pp. 1-31.

[11] Andersen, B., Henriksen, B. \& Aarseth, W. 2007. Benchmarking of project management office establishment: Extracting best practices. J. Manag. Eng., 23(2),pp. 97-104.

[12] Hill, G.M. 2004. Evolving the project management office: A competency continuum. Inf. Syst. Manag., 21(4),pp. 45-51.

[13] Liu, L. \& Yetton, P. 2007. The contingent effects on project performance of conducting project reviews and deploying project management offices. IEEE Trans. Eng. Manag. , 54(4), pp. 789-799.

[14] Rad, P.F. 2001. Is your organization a candidate for project management office PMO? AACE Int. Trans., 7(1), pp. 07.1-07.4.

[15] Knoblauch, C.J. 1998. Knowledge management - taking advantage of what you know. In Proceedings of the Integrated Online Library Systems Meeting Conference. Location: New York, NY Conference, pp. 71-83.

[16] Kasvi, J.J.J., Vartiainen, M. \& Hailikari, M. 2003. Managing knowledge and knowledge competences in projects and project organisations. Int. J. Proj. Manag., 21(8), pp. 571-582.

[17] Durst, S. \& Runar, I. 2012. Knowledge management in SMEs: A literature review. J. Knowl. Manag., 16(6), pp. 879903.

[18] Liebowitz, J. \& Megbolugbe, I. 2003. A set of frameworks to aid the project manager in conceptualizing and implementing knowledge management initiatives. Int. J. Proj. Manag., 21(3), pp. 189-198.

[19] Lee, S., Gon Kim, B. \& Kim, H. 2012. An integrated view of knowledge management for performance. J. Knowl. Manag., 16(2), pp. 183-203.

[20] Sokhanvar, S., Matthews, J. \& Yarlagadda, P. 2014. Importance of knowledge management processes in a projectbased organization: A case study of research enterprise. Procedia Eng., 97, pp. 1825-1830.

[21] Tshuma, B., Steyn, H. \& Van Waveren, C. 2018. The role played by PMOs in the transfer of knowledge between projects: A conceptual framework. South African J. Ind. Eng., 29(2), pp. 127-140.

[22] Cummings, J.L. \& Teng, B. 2003. Transferring R \& D knowledge: The key factors affecting knowledge transfer success. J. Eng. Technol. Manag., 20, pp. 39-68.

[23] Fernie, S., Green, S.D., Weller, S.J. \& Newcombe, R. 2003. Knowledge sharing: Context, confusion and controversy. Int. J. Proj. Manag., 21, pp. 177-187.

[24] Dhanaraj, C., Lyles, M.A., Steensma, H.K. \& Tihanyi, L. 2004. Managing tacit and explicit knowledge transfer in IJVs: The role of relational embeddedness and the impact on performance. J. Int. Bus. Stud., 35, pp. 428-442.

[25] Owen, J., Burstein, F. \& Mitchell, S. 2004. Knowledge reuse and transfer in a project management environment. J. Inf. Technol. Case Appl. Res., 6(4), pp. 21-35.

[26] Julian, J. 2008. How project management office leaders facilitate cross-project learning and continuous improvement. Proj. Manag. J., 39(3), pp. 43-58.

[27] Fong, P.S.W. \& Kwok, C.W.C. 2009. Organizational culture and knowledge management success at project and organizational levels in contracting firms. J. Constr. Engineering Manag., 135(12), pp. 1348-1357.

[28] Curlee, W. 2008. Modern virtual project management: The effects of a centralized and decentralized project management office. Proj. Manag. J., 39, pp. 583-596.

[29] Yin, R.K. 2014. Case study research: Design and methods, 5th ed. Sage Publications Ltd - London.

[30] Rowley, J. 2002. Using case studies in research. Manag. Res. News, 25(1), pp. 16-27.

[31] Van Teijlingen, E. \& Hundley, V. 2002. The importance of pilot studies. Nurs. Stand., 16(40), pp. 33-36.

[32] Leon, A.C., Davis, L.L. \& Kraemer, H.C. 2011. The role and interpretation of pilot studies in clinical research. J. Psychiatr. Res., 45(5), pp. 626-629.

[33] Jacob, S.A. \& Furgerson, S.P. 2012. Writing interview protocols and conducting interviews: Tips for students new to the field of qualitative research. Qual. Rep., 17(42), pp. 1-10.

[34] Eisenhardt, K.M. 1989. Building theories from case study research. J. Manag. Rev., 14(4), pp. 532-550.

[35] Eisenhardt, K.M. 2010. Case study research. In PMI Research and Education Conference, Washington DC.

[36] Rubin, H.J. \& Rubin, I.S. 1995. Qualitative interviewing: The art of hearing data. 3rd ed. Sage Publications Ltd London.

[37] Unger, B.N., Gemünden, H.G. \& Aubry, M. 2012. The three roles of a project portfolio management office: Their impact on portfolio management execution and success. Int. J. Proj. Manag., 30(5), pp. 608-620.

[38] Heisig, P. 2009. Harmonisation of knowledge management: Comparing $160 \mathrm{KM}$ frameworks around the globe. J. Knowl. Manag., 13(4), pp. 4-31.

[39] Jafari, N. \& Charband, Y. 2016. Knowledge sharing mechanisms and techniques in project teams: Literature review, classification, and current trends. Comput. Human Behav., 62, pp. 730-742.

[40] Van Waveren, C.C., Oerlemans, L.A.G. \& Pretorius, M.W. 2014. Knowledge transfer in project-based organizations: A conceptual model for investigating knowledge type, transfer mechanism and transfer success. 2014 IEEE International Conference on Industrial Engineering and Engineering Management, Bandar Sunway., pp. 1176-1181.

[41] Nielsen, B.B. 2005. The role of knowledge embeddedness in the creation of synergies in strategic alliances. J. Bus. Res., 58, pp. 1194-1204.

[42] Higuchi, Y. \& Yamanaka, Y. 2017. Knowledge sharing between academic researchers and tourism practitioners: A Japanese study of the practical value of embeddedness, trust and co-creation. J. Sustain. Tour., 25(10), pp. 14561473.

[43] Bellini, A., Aarseth, W. \& Hosseini, A. 2016. Effective knowledge transfer in successful partnering projects. Energy Procedia, 96(1876), pp. 218-228.

[44] Prinsloo, J.W., Van Waveren, C.C. \& Chan, K.-Y. 2017. Factors that impact knowledge dissemination in projects. South African J. Ind. Eng., 28(1), pp. 1-11. 
[45] Bond-Barnard, T.J., Fletcher, L. \& Steyn, H. 2018. Linking trust and collaboration in project teams to project management success. Int. J. Manag. Proj. Bus., 11(2), pp. 432-457.

[46] Bond-Barnard, T.J., Steyn, H. \& Fabris-Rotelli, I. 2013. The impact of a call centre on communication in a programme and its projects. Int. J. Proj. Manag., 31(7), pp. 1006-1016.

[47] Alsharo, M., Gregg, D. \& Ramirez, R. 2016. Virtual team effectiveness: The role of knowledge sharing and trust. Information \& Management., 54(4), pp. 479-490.

[48] Hsiao, R., Tsai, S.D., Lee, C., Dun-hou, S. \& Lee, C. 2005. The problems of embeddedness: Knowledge transfer, coordination and reuse in information systems. Organ. Stud., 27(9), pp. 1289-1317.

[49] Susanty, A., Utami, N. \& Yugi, M. 2012. Key success factors that influence knowledge transfer effectiveness: A case study of Garment Sentra at Kabupaten Sragen. Procedia Econ. Financ., 4, pp. 23-32.

[50] Lindner, F. \& Wald, A. 2011. Success factors of knowledge management in temporary organizations. Int. J. Proj. Manag., 29(7), pp. 877-888.

[51] Schindler, M. \& Eppler, M.J. 2003. Harvesting project knowledge: A review of project learning methods and success factors. Int. J. Proj. Manag., 21(3), pp. 219-228.

[52] Eskerod, P. \& Skriver, H.J. 2007. Organizational culture restraining in-house knowledge transfer between project managers: A case study. Proj. Manag. J., 38(1), pp. 110-122.

[53] Knowledge Research Institute. 2000. Knowledge transfer processes. Knowledge Resources Institute, Inc - London.

[54] Rowley, J. 1999. What is knowledge management? Libr. Manag., 20(8), pp. 416-420.

[55] Newell, S. 2004. Enhancing cross-project learning. Eng. Manag. J., 16(1), pp. 12-20.

[56] Karlsen, J.T. \& Gottschalk, P. 2004. Factors affecting knowledge transfer in IT projects. Eng. Manag. J., 16(1), pp. 3-11.

[57] Chourides, P., Longbottom, D. \& Murphy, W. 2003. Excellence in knowledge management: An empirical study to identify critical factors and performance measures. Meas. Bus. Excell., 7(2), pp. 29-45.

[58] Gold, A.H., Malhotra, A. \& Segars, A.H. 2001. Knowledge management: An organizational capabilities perspective. J. Manag. Inf. Syst., 18(1), pp. 185-214.

[59] Julian, J. 2008. How project management office leaders facilitate cross-project learning and continuous improvement. Proj. Manag. J., 39(3), pp. 43-58.

[60] Carrillo, P.M., Robinson, H.S., Anumba, C.J. \& Bouchlaghem, N.M. 2006. A knowledge transfer framework: The PFI context. Constr. Manag. Econ., 24(October), pp. 1045-1056.

[61] Choi, B., Poon, S.K. \& Davis, J.G. 2008. Effects of knowledge management strategy on organizational performance: A complementarity theory-based approach. Int. J. Manag. Sci., 36, pp. 235-251.

[62] Brady, T. \& Davies, A. 2004. Building project capabilities: From exploratory to exploitative learning. Organ. Stud., 25(9), pp. 1601-1621.

[63] Shannak, R.O. 2009. Measuring knowledge management performance. Eur. J. Sci. Res., 35(2), pp. $242-253$.

[64] Straus, S.E., Tetroe, J., Graham, I.D., Zwarenstein, M., Bhattacharyya, O. \& Shepperd, S. 2010. Monitoring use of knowledge and evaluating outcomes. Can. Med. Assoc. J., 182, pp. E94-E98.

[65] McClory, S., Read, M. \& Labib, A. 2017. Conceptualising the lessons-learned process in project management: Towards a triple-loop learning framework. Int. J. Proj. Manag., 35(7), pp. 1322-1335.

[66] Malone, D. 2002. Knowledge management: A model for organizational learning. Int. J. Account. Inf. Syst., 3, pp. 111-123. 
Analysis of interview methods used in the interview and recommendations for the main case based on Jacob and Furgerson [33]

\begin{tabular}{|c|c|c|}
\hline Item & Interview protocol & Analysis and recommendations \\
\hline a. & $\begin{array}{l}\text { Choose a topic interesting to you } \\
\text { to mitigate the risk of losing } \\
\text { interest during the research } \\
\text { process. }\end{array}$ & $\begin{array}{l}\text { This was done from the outset of the research study. Not only is the } \\
\text { topic interesting, but it is real and practical, and speaks to present- } \\
\text { day shortcomings that require detailed exploration and exploitation. }\end{array}$ \\
\hline b. & $\begin{array}{l}\text { Interview questions should be } \\
\text { guided by the research topic and } \\
\text { literature to help the interviewer } \\
\text { to gather only relevant } \\
\text { information. }\end{array}$ & $\begin{array}{l}\text { Interview questions are guided by the research questions that are } \\
\text { grounded in the literature and that were sent a month prior to the } \\
\text { initially proposed interview date. A follow-up email was sent to the } \\
\text { respondent to check whether she needed further clarification and/or } \\
\text { additional information. The response was that all was clear, and no } \\
\text { further clarification and/or information was required. }\end{array}$ \\
\hline c. & $\begin{array}{l}\text { Use a script at the beginning and } \\
\text { end of the interview to ensure } \\
\text { that the respondent understands } \\
\text { the phenomenon being studied and } \\
\text { its context. }\end{array}$ & $\begin{array}{l}\text { A script was used at the beginning and at the end of the interview } \\
\text { session, as can be seen in the pilot study's transcribed interview. At } \\
\text { the beginning of the interview the interviewer shared critical details } \\
\text { about the study (research topic, objectives, questions and } \\
\text { propositions, definitions of key words, conceptual framework, and } \\
\text { methodology). The outline of the processes after the interview were } \\
\text { also indicated to the respondent towards the end of the interview. }\end{array}$ \\
\hline d. & $\begin{array}{l}\text { Avoid closed-ended questions and } \\
\text { make use of open-ended questions } \\
\text { to explore as much information } \\
\text { about the question as possible. }\end{array}$ & $\begin{array}{l}\text { Closed-ended questions were avoided at all costs. In instances where } \\
\text { the respondent said only 'yes' or 'no' or gave very short answers, the } \\
\text { interviewer raised follow-up questions and guided the respondent } \\
\text { towards the intended focus areas. }\end{array}$ \\
\hline e. & $\begin{array}{l}\text { Start with the basics to warm up } \\
\text { the respondent. }\end{array}$ & $\begin{array}{l}\text { The interviewer and respondent knew each other very well from } \\
\text { previous projects. Before the interview started, they chatted about } \\
\text { general items, which helped the respondent to relax. }\end{array}$ \\
\hline f. & $\begin{array}{l}\text { Begin with easy -o-answer } \\
\text { questions and move towards ones } \\
\text { that are perceived to be more } \\
\text { difficult or controversial to build } \\
\text { confidence and trust with the } \\
\text { respondent slowly. }\end{array}$ & $\begin{array}{l}\text { Questions perceived to be easy and simple to respond to were asked } \\
\text { first, while the difficult and controversial ones were asked later, to } \\
\text { increase the confidence of the respondent. }\end{array}$ \\
\hline g. & $\begin{array}{l}\text { The phrase "tell me about ..." is a } \\
\text { great way to start a question, as it } \\
\text { is not only an invitation for the } \\
\text { respondent to tell a story, but } \\
\text { subtly commands the respondent } \\
\text { to begin talking. }\end{array}$ & $\begin{array}{l}\text { This strategy was used and worked perfectly well. However, long } \\
\text { questions ended up confusing the respondent, to the extent that the } \\
\text { interviewer had constantly to repeat and elaborate on them. This took } \\
\text { up a lot of time. It is therefore recommended that interview questions } \\
\text { be revised to be short and straight to the point. }\end{array}$ \\
\hline h. & $\begin{array}{l}\text { Write big, expansive questions to } \\
\text { allow the respondent to take your } \\
\text { question in several directions, } \\
\text { giving you an all-round } \\
\text { perspective. }\end{array}$ & $\begin{array}{l}\text { Although structuring big, expansive interview questions led to the } \\
\text { respondent saying things that the interviewer never thought to ask, } \\
\text { and in other instances led to the respondent going off-topic, this } \\
\text { helped in mitigating the risk of being biased towards or against a view } \\
\text { or point. }\end{array}$ \\
\hline i. & Use probes or prompts. & $\begin{array}{l}\text { This is an area that needs to be revisited and corrected before the } \\
\text { main case study can be conducted. Broad questions were designed } \\
\text { and incorporated into the interview questionnaire. However, prompts } \\
\text { (sub-questions that have emerged from the literature, or questions } \\
\text { that may enrich the data) were not incorporated in the questionnaire. } \\
\text { This led to the respondent not addressing all the aspects of the } \\
\text { intended areas. Consequently, a lot of follow-up questions, for which } \\
\text { the respondent was not ready, were raised. This irritated the } \\
\text { respondent, as her facial expression indicated that she was being put } \\
\text { on the spot. For example, questions about the PMO's role in the } \\
\text { interaction of knowledge transfer infrastructure and processes were } \\
\text { not adequately addressed by the respondent. A table showing the } \\
\text { areas of interest underlying these questions is recommended for the } \\
\text { main case study. }\end{array}$ \\
\hline j. & $\begin{array}{l}\text { Be willing to make on-the-spot } \\
\text { revisions to your interview } \\
\text { protocol. }\end{array}$ & $\begin{array}{l}\text { This aspect was adequately handled during the interview. On-the-spot } \\
\text { revisions were prompted by the respondent's responses. }\end{array}$ \\
\hline
\end{tabular}




\begin{tabular}{|c|c|c|}
\hline Item & Interview protocol & Analysis and recommendations \\
\hline k. & $\begin{array}{l}\text { Avoid making the interview too } \\
\text { long, lest the respondent gets } \\
\text { tired, or loses concentration and } \\
\text { interest. }\end{array}$ & $\begin{array}{l}\text { The interview was overrun by only five minutes, mainly due to the } \\
\text { venue change after the interview had started. The interview time } \\
\text { could be shortened by shortening the research questions to avoid } \\
\text { having to clarify them before the respondent could respond. }\end{array}$ \\
\hline l. & $\begin{array}{l}\text { Rehearse the interview session } \\
\text { with a friend before conducting } \\
\text { the actual interview. }\end{array}$ & $\begin{array}{l}\text { Although the interviewer prepared well before the interview, the } \\
\text { interview was not rehearsed. Had the interview been rehearsed, most } \\
\text { of the shortcomings could have been eliminated. The researcher } \\
\text { undertakes to rehearse all interviews of the main case study before } \\
\text { conducting interviews to eliminate shortcomings and make the } \\
\text { process effective and efficient. }\end{array}$ \\
\hline $\mathrm{m}$. & $\begin{array}{l}\text { Set up a second shorter interview } \\
\text { in advance, to help you clarify or } \\
\text { ask any questions you missed after } \\
\text { transcribing the interview. }\end{array}$ & $\begin{array}{l}\text { This was not done in advance and may not go down well with the } \\
\text { respondent if a second shorter interview is suddenly scheduled when } \\
\text { this was not communicated to her from the outset. This is a good } \\
\text { lesson learnt, and it will be implemented in the main case study } \\
\text { interviews. }\end{array}$ \\
\hline $\mathrm{n}$. & $\begin{array}{l}\text { Make use of a recording device, } \\
\text { and only take brief notes so you } \\
\text { can maintain eye contact with the } \\
\text { respondent. }\end{array}$ & $\begin{array}{l}\text { This was perfectly handled during the interview. Recording the } \\
\text { interview also gives the interviewer time to digest responses from the } \\
\text { respondent, and to ask appropriate follow-up questions or confine the } \\
\text { respondent to the research questions in case he or she goes off-topic. }\end{array}$ \\
\hline 0. & $\begin{array}{l}\text { Arrange the interview in a quiet, } \\
\text { semi-private place. }\end{array}$ & $\begin{array}{l}\text { Although a boardroom was booked in advance for the interview, the } \\
\text { session was interrupted by the respondent's colleagues who wanted to } \\
\text { use the same boardroom. We had to find a smaller boardroom. } \\
\text { Although it took us less than five minutes to find another boardroom, } \\
\text { this interruption negatively affected the rhythm of the interview, and } \\
\text { the researcher had to 'warm up' the respondent again. To avoid } \\
\text { similar instances happening in future, interview venue bookings will } \\
\text { be done by the researcher. }\end{array}$ \\
\hline p. & $\begin{array}{l}\text { Avoid interruptions during the } \\
\text { interview. }\end{array}$ & $\begin{array}{l}\text { The interviewer's phones were put on flight mode and used for } \\
\text { recording the interview. Two phones were used as back-up in case one } \\
\text { did not record. The respondent, however, insisted on putting her } \\
\text { phone on silent so that she could track all missed calls and messages } \\
\text { after the interview. This worked well. }\end{array}$ \\
\hline q. & $\begin{array}{l}\text { Have genuine care and concern } \\
\text { for, and interest in, the } \\
\text { respondent to avoid their losing } \\
\text { interest in the interview. }\end{array}$ & $\begin{array}{l}\text { This is one of the more delicate, if not difficult, items to manage. } \\
\text { Failure to manage this aspect can sabotage the interview. Keeping } \\
\text { constant eye-contact, showing respect and kindness, speaking with a } \\
\text { clear and unambiguous voice, and being lively during the interview } \\
\text { kept the respondent interested most of the time. However, she } \\
\text { became frustrated by the frequency of the follow-up questions that } \\
\text { she did not anticipate. This will be corrected in the next interviews, } \\
\text { as alluded to earlier. }\end{array}$ \\
\hline r. & $\begin{array}{l}\text { Be a good listener and avoid } \\
\text { interrupting the respondent before } \\
\text { they have made their point. }\end{array}$ & $\begin{array}{l}\text { The researcher needs to refrain from constantly finishing off the } \\
\text { respondent's responses, as this may be viewed as bias. In cases where } \\
\text { the respondent forgets a word or words, instead of bluntly assisting } \\
\text { the respondent to finish the sentence, the interviewer should rather } \\
\text { ask the respondent if the provided word(s) is/are what they had been } \\
\text { wanting to say, to increase the reliability of the study. }\end{array}$ \\
\hline s. & $\begin{array}{l}\text { Keep the interview focused and } \\
\text { avoid off-topic discussions. }\end{array}$ & $\begin{array}{l}\text { Because of time constraints, this was perfectly managed. As soon as } \\
\text { the respondent went off-topic, the researcher quickly brought her } \\
\text { back on track. }\end{array}$ \\
\hline
\end{tabular}

